ELORE (ISSN 1456-3010), vol. 16 - 1/2009.

Julkaisija: Suomen Kansantietouden Tutkijain Seura ry. [http://www.elore.fi/arkisto/1_09/katsausart_virtanen_1_09.pdf]

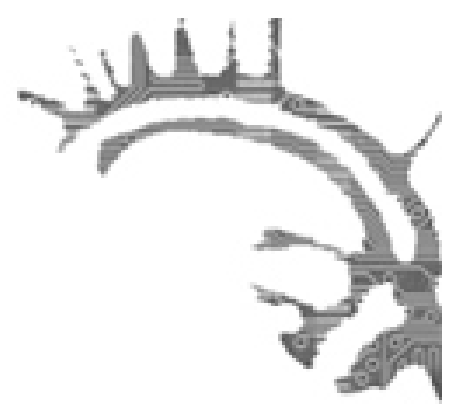

KATSAUSARTIKKELI:

\title{
FOLKLORISTI MUSEOSSA
}

\author{
Pekka Virtanen
}

Museoalalle suuntautuminen ei ollut ensimmäinen vaihtoehto, joka tuli 1980-luvulla Helsingin yliopiston folkloristiikan pääaineopiskelijalle mieleen. Perinneaineiden selkeä jaottelu aineellisen ja henkisen kulttuurin tutkimukseen tai historia-aineisiin kuuluva virallisten dokumenttien kunnioittaminen heijastuivat myös kelvollisten museoaineiden määrittelyihin. Esimerkiksi kansatieteen ja arkeologian esinepainotteisuus oli paljon enemmän museoon päin kallellaan kuin suomalainen ja vertaileva kansanrunoudentutkimus. Yksittäisten museoaineiden (Helsingissä kansatiede, historia, arkeologia, taidehistoria) omat museokurssit ja yhteiset museotekniikan kurssit oli kohdistettu pääasiassa niiden pääaineopiskelijoille. Oppiaineiden tarjoamat ammatilliset reittivaihtoehdot ja osaltaan myös oma, opiskelun alkuvaiheen kapea näkemys museotoiminnan todellisista ja mahdollisista sisällöistä eivät innostaneet folkloristia museoalalle. Tosin 1980-luvun opiskeluaikana monet toimeni sivusivat museota lähellä olevia, tutkimukseen ja näyttelyihin liittyviä kulttuurinäkökulmia, mutta esimerkiksi vireille lähtenyttä metsämuseohanketta seurasin vain sivusilmin.

\section{Museota PerustamaAn}

Vuonna 1991 sain kutsun tulla mukaan valmistelemaan Punkaharjulle metsämuseota, jossa työskentelin aina vuoteen 2006 saakka. Leveiden työmaiden myötä hälvenivät ennakkomielikuvat pölyttyneestä museosta. Uudesta museosta oli määrä tehdä moniulotteinen kulttuurilaitos. Se oli saava modernit arkkitehtoniset puitteet ja sisällön tekijöiksi harvalukuisen mutta innokkaan tekijäjoukon. Päätyönäni oli perusnäyttelyn hahmon luominen, mutta pian huomasin olevani mukana kokonaisen museotoiminnan perustamistöissä vasarahommista aina metsä-, museo- ja kulttuurialan verkostojen luomiseen. 


\section{FOLKLORISTI MUSEOSSA}

Myöhemmin Lustoksi nimetyn metsämuseon rakenteluissa mentiin vauhdilla eteenpäin, sillä ensivaiheen piti olla valmis kolmessa vuodessa tiloineen, kokoelmineen, näyttelyineen ja muine toimintoineen. Vuosikymmenen alussa oli kyllä vielä aistittavissa vanhaa museoajattelun henkeä. Oli vankkoja käsityksiä pyhän museon olemuksesta, johon kuuluivat sovinnaiset esittämistavat ja toiminnalliset raja-aidat. Sopiiko esimerkiksi museomyymälä tai ravintola museon yhteyteen? Voiko perinteisesti rajoistaan huolehtivia museotyyppejä (kulttuurihistoria, taide, luonnontiede tai tiedekeskus) sekoittaa keskenään? Vastaavasti metsäalojen viestinnällä oli omat vakiintuneet käytäntönsä. Museo- ja tietokeskustoiminta erotettiin nimitarkennuksen myötä toisistaan, vaikka käytännössä toiminta tapahtui "museokonseptin" mukaisesti. (Virtanen 1997, 26-33.) Sittemmin "Lusto - Suomen metsämuseo ja metsätietokeskus" onkin luopunut jälkimmäisestä metsätietokeskus-liitteestä. Kieliikö edellinen yleisemmällä tasolla siitä, että museo nähdään jo laaja-alaisena myös nykyaikaa kartoittavana instituutiona vai siitä, että museon annetaan rauhassa keskittyä vanhoihin asioihin?

Museot ja museologinen ajattelu olivat 1990-lukua lähestyttäessä olleet pitkään muutoksien tilassa tai ainakin niiden odotuksessa. Tieteen suunnalla alettiin puhua uudesta museologiasta (Vilkuna 2003, 5-10). Näyttelyjen kielen uudistamisesta oli keskusteltu silloin tällöin, esimerkkinä Jukka Pennasen kehotus katsella museoista ohi porskuttavien tiedekeskusten suuntaan (Pennanen 1985, 18). Museokonseptien muutoksiin ei kaikkialla lähdetty heti mukaan, mutta 1990-luvun kuluessa esimerkiksi Kiasma, Vapriikki ja Postimuseo kehittivät isostikin toimintaansa uusien tuulien saattelemana. Tiedekeskus Heureka oli kasvanut tahollaan. Yhtenä pontimena kaikilla olivat varmasti uusien tilojen tuomat puitteet ja virikkeet. Samaisessa hengessä Lustokin oli ollut liikkeellä.

Uudenlaiset museotuulet eivät tulleet Suomeen ihan tyhjästä. Esimerkiksi Pohjoismaissa tapahtui 1980-luvulla monenlaista uutta, johon pääsin omakohtaisesti tutustumaan vireästi toimivan Nefa-Nordenin kokousten ja projektien ansiosta. Moni pohjoismaalainen nefa-aktivisti oli töissä museossa ja muutenkin kokousten yhteydessä tulivat tutuiksi kokouspaikkakuntien museot taustoineen. Kulttuurintutkimus ja siihen liittyvä toiminta tuntui kokonaisuudessaan lännessä muutenkin raikkaalta. Kunnianhimoisten näyttelyiden ohella suomalainen opiskelija ihmetteli esimerkiksi Ruotsissa nykyisellään noin 80 museon Samdok-verkostoa, jonka piirissä pohdittiin ja organisoitiin nykypäivän dokumentointia (Connecting... 2007). Tanskassa tutustuminen tärkeään asemaan nousevaan museopedagogiaan oli avartavaa. Että esimerkiksi koululuokkaa ei viedäkään noin vaan siltä istumalta ja kylmiltään museon, vaan sitä saattoi edeltää kuukausien tutustuminen etukäteisaineistoihin, joihin perehdyttämisessä myös opettajilla oli suuri rooli!

Vuosien varrella olen ymmärtänyt Ruotsin vireän näyttelytoiminnan taustoja ja syitä. Yli 40 vuotta sitten perustettu valtion rahoittama, yli 60 vakiotyöntekijän organisaatioksi kasvanut, nyttemmin Gotlannissa päämajaansa pitävä Riksutställningar keskittyi vain näyttelytoimintaan. Hyvin tehtyjen, kokeellisuutta kaihtamattomien näyttelyiden sekä julkaisu- ja opetustoiminnan heijastusvaikutukset ulottuivat museoiden ja muiden tahojen näyttelytoimintaan. Suuri näyttelyorganisaatio sai kritiikkiäkin. Sen ajateltiin vievän liikaa rahaa museoiden omalta toiminnalta. Myös näyttelyjen sisältöjä arvosteltiin. (Virtanen 2007) 


\section{PekKa Virtanen}

Nefa-toiminnassa eivät korostuneet etnologian ja folkloristiikan väliset erot, mistä syystä ehkä huomaamatta tuli altistuttua museopölylle. Yliopiston varsinaisissa opinnoissa ei linkkejä museomaailmaan juuri ollut. Museoon ohjaavia suuntaviittoja olisi ollut muuallakin. Suomessa museotoiminnasta ja myös museo-opetuksesta tietoa jakoi yliopiston lisäksi erityisesti Museoliitto. Yliopistotason museologian opetus käynnistyi esimerkiksi Jyväskylässä 1983, jossa ainoana paikkakuntana on tänä päivänä mahdollisuus edetä oppiaineessa aina väitöskirjaan asti. Vahva folkloristi-identiteettikin lienee ollut syynä siihen, että museologiaan ajatukseni eksyivät vain harvoin. Näin vaikka varsinkin nykyisin alan määrittely vaikuttaa varsin houkuttelevalta. Janne Vilkunan sanoin "museologia (heritologia) on tiede, joka tarkastelee sitä, kuinka yksilö ja yhteisö hahmottaa ja hallitsee ajallista ja alueellista ympäristöään ottamalla haltuun menneisyyden ja nykyisyyden todistuskappaleita.” (Vilkuna 2003,10.)

Tämän päivän yliopistojen museologian opetusta Helsingissä, Turussa, Tampereella, Jyväskylässä ja Oulussa sekä ainejärjestöjen toimintaa seuraava näkee virkeyttä ja uusia näkymiä. Myös museoiden, museoalan yhteisöjen ja muiden toimijoiden piirissä ilmenee uudenlaista tekemisen luovuutta, jota ei vielä 1980-luvulla päästetty museolinnoitusten sisään.

\section{TAPAHTUMia, DOKUMENTOINTIA JA TUTKIMUSTA}

Metsämuseon nostatustöiden alkaessa minulla oli alkuvaiheessa petrattavaa museoalan tietämyksessä. Toiminnoiltaan laaja-alaisen kulttuurilaitoksen leveiden työmaiden edessä oli hyvä muistutella mieleen kaikilta rintamilta saatuja oppeja. Hiukan oli pelkojakin. Aikoinaan 1980-luvulla olin ollut jonkin verran mukana HYY:n Kulttuurikeskuksen toimissa ja samaan aikaan mielenkiinnolla seurasin valtion ja kuntien toimia kulttuurisihteerien märän lisäämiseksi. Silloin monipuolisesti toimivan Kulttuurikeskuksen kokemuksen perusteella näytti siltä, että kulttuuritoimijoille olisi avautumassa ainakin potentiaalisesti avarat työmaat, eikä lainkaan epäsopivat folkloristiikka-taustaisillekaan. Mutta korviin kantautui kulttuurisihteerikentältä muuta. Luovan tuottamisen sijaan työ olikin usein kissanristiäisten järjestämisistä, tuolien siirtelyä ja muuta järjestelytyötä. Taloudellisiin seikkoihin vedoten kulttuurisihteerivelvoitteet alkoivat sittemmin poistua vähin äänin. Alas ajettiin myös HYY:n Kulttuurikeskus.

Metsämuseorintamalla pientä huolta oli siitä, ettei vaan mikään pysäyttäisi tai vaikeuttaisi hankkeen virkeätä etenemistä. Isoin mahdollinen vastavoima sitten ilmaantuikin. Lama alkoi pysäytellä valtion hankkeita ja jos ei ihan päivistä tai viikoista, niin kuukausista saattoi olla kiinni rahoituspäätösten hyväksymiset ja hylkäämiset. Huonot ajat tulivat nopeasti. Lustonkin rakentamisessa mukana olleista taisi arkkitehtitoimisto olla ainoa, joka ei ajautunut konkurssiin tai muuten suuriin vaikeuksiin. Museohanke kuitenkin eteni vaikka esimerkiksi talon näyttelybudjetti oli auki vielä runsaat puoli vuotta ennen avajaisia.

Metsämuseota rakennettaessa folkloristiset taustakysymykset nousivat monesti mieleeni ja sen myötä pohdinnat yleisemmistä yliopisto-oppien synnyttämistä 


\section{FOLKLORISTI MUSEOSSA}

museonäkymistä. Ihmeteltävää museoissa saattoi olla esimerkiksi kansatieteellisen näkökulman vahvuus kansanelämän esittelyissä tai arkeologian ja historian painottuminen toisaalla. Folklorististen teemojen ja sanomistapojen vähäisyys näyttelyissä tai museotoiminnassa on ollut vallitseva käytäntö, johon folkloristit ovat kyllä silloin tällöin kirjoituksissakin aiheellisesti puuttuneet. (Lehtipuro 1995, 16-19, Saressalo 1994, 2-3). Turun yliopiston Kulttuurien tutkimuksen laitos oli Nefa-Turun vanavedessä 1982 jopa ehdottanut Museoliitolle, että se "suosittelisi piiriinsä kuuluville museoille ja niiden hallintoelimille kansanrunoudentutkimuksen huomioonottamista museovirkoja täytettäessä pätevyyttä lisäävänä aineena”. Pyrkimys ei ollut päästä museoalan suuntautumisvaihtoehdon päävastuuaineeksi, silti vastaus oli kieltävä: "... Suomen Museoliiton keskushallitus ei katsonut voivansa suositella kansanrunouden korvaavan perinteellisiä esineellistä kulttuuria tutkivia tieteenaloja”. (Saressalo 1982, 3-5.)

Näyttelyiden tekemisen lisäksi folkloristilla on paikkansa museossa perinteen keruussa. Suullisen perinteen ja nykyisin myös kirjallisen muistelun kenttää on museoissa painotettu vaihtelevasti. Museon tarpeisiin saattaa riittää esineen perustietojen ylös ottaminen vuosi-, valmistaja-, omistus- ja käyttötietomerkintöineen. Tässä vaiheessa alkaa folkloristi oikeastaan vasta lämmetä. Tosin tunninkin haastattelu litterointeineen on usein resurssikysymys. Museotyössä ei ole useinkaan aikaa pitkiin haastatteluhetkiin. Toisaalta nykyaikana museoiden, kansatieteen tai folkloristiikan keruutavoitteet eivät välttämättä eroa kovinkaan paljoa toisistaan silloin, kun kyseessä ovat suuret, ilmiökeskeiset ja hyvin suunnitellut, kokonaisvaltaiset dokumenttiprojektit. Esimerkiksi Lustoon on tallennettu monia keruuaineistoja, jotka tarjoavat hyviä tutkimuksellisia lähtökohtia niin folkloristille kuin kansatieteilijällekin.

Museon tehtäviin kuuluu tallentamisen ohella tutkimus. Kuitenkin vain keskusmuseoilla ja joillakin isoimmilla museoilla on omien resurssien puitteissa mahdollisuuksia laajoihin, itsenäisiin ja yliopistollista tutkimustyötä vastaaviin pitkäaikaisiin hankkeisiin. Ulkoistaminen on tietenkin mahdollista, jos löytyy rahoitusta ja sisäistä näkemystä. Usein museoammattilainen, tutkija-nimikkeelläkin, keskittyy enemmän esine-, taide- tai valokuvakokoelman hallintaan tai näyttelyjen koostamiseen kuin vaikkapa pitkäaikaiseen uittokaluston kehityskaaren vertailuun. Kummassakin tapauksessa voi tutkimuksellisesta perspektiivistä edetä analyyttisiin, uusiin ja tieteellisesti relevantteihin tuloksiin, jotka museossa palvelevat sen omia tarpeita. Sellainen voi olla vaikkapa kokoelmiin liittyvä puutelista.

Vähän aikaa sitten tein museologiaa ja museo-oppeja kartoittavan haastattelukierroksen ja siinä yhteydessä viitattiin myös esinetutkimukseen. Samalla kun valiteltiin nykyistä tutkimuksen vähäisyyttä esimerkiksi museoiden tarpeisiin, ilmeni kaipausta uudenlaisista lähtökohdista nousevaan esinetutkimukseen. (Virtanen 2008, 14-16.) Ei tarvitse viitata moneenkaan folkloristiseen julkaisuun kun voi jo huomata, että oppiaineella onkin yllättäen monenlaista tarjottavaa myös tällä saralla, tapahtuipa se museossa tai muualla (ks. esim. Aarnipuu 2008, Stark 2007). Esinekammoiselle folkloristille virkistävää luettavaa on myös Roger-Pol Droitin (2005) Esineiden luonto.

Eri oppiaineiden lähestymistavat saattavat mennä päällekkäin. Esimerkiksi Petja Aarnipuun Turun linnaa koskeva folkloristiikan alan tutkimus voisi melkeinpä sellaisenaan sopia museologian väitöskirjaksi Jyväskylään (ks. Aarnipuu 2008). Toisissa 


\section{PekKa Virtanen}

kohden on nähty suurtakin vastakkaisuutta. Esimerkiksi museologiaan liittyvä teorian ja käytännön samanaikaisuus on virittänyt oppiaineeseen kohdistuvia jännitteitä. Museoissa museologia on saatettu kokea liian teoreettisena ja sen museotyöhön tarjoamat eväät puutteellisina. Yliopistoissa oppiaineen tieteellisyyttä on taasen aliarvostettu juuri sen käytännönläheisyyden takia. (Virtanen 2008, 14-16) Todellisuudessa museologia tarjoaa teitä sekä pitkälle vietyyn teoreettiseen tutkimukseen että käytännön museotyöhön. Samankaltaista vastakkainasettelua teoreettisen tiedon vaalimisen ja käytännön välillä oli näkyvissä esimerkiksi 1900-luvun alussa, kun korkeinta maatalous- ja metsätieteellistä opetus- ja tutkimustoimintaa aloiteltiin Helsingin yliopistossa (Halonen 2008, 213-220). Pelättiin tieteeseen kuulumatonta "navetan hajua". Samoilta suunniltahan ovat peräin myös pihkan ja kämppien hajumaailmat.

\section{NÄYTTELYMEDIA}

Museon tehtäviin kuuluu näytteille asettaminen, mikä tiedottamisen tapana eroaa suuresti esimerkiksi yliopistollisesta viestintäkulttuurista, postereineenkin. Yliopistojen nykyisessä muutoskehityksessä tapahtuva pohdinta sen yhteiskunnallisesta merkityksestä saattaa muuttaa asetelmaa. Yliopistolliset johdatukset tieteen maailmaan eivät pohjimmiltaan eroa museon pedagogisista linjoista, eli tutkimusperustaista totta pitäisi molemmissa kertoa. Museossa kohderyhmä ei ole samalla tavoin rajattu kuin yliopistossa. Museonäyttelyssä ja -toiminnassa kaikki informaalisen opetuksen keinot ovat myös mahdollisia (ks. esim. Salmi 2001). Popularisoinnin, ymmärrettävyyden, tiedetietämyksen jne. näkökulmat ovatkin museon, tiedekeskusten ja museologian kannalta mielenkiintoisia ja varmasti liian vähän pohdittuja asioita.

Popularisoinnin merkitys on parin vuosikymmenen kuluessa muuttunut. On syntynyt paljon uusia tieteenaloja ja tieteenalojen sisällä on erikoistuttu niin, että tieteiden sisäinen vertaisviestintä toimii entistä kapeammalla alueella (Kiikeri ja Ylikoski 2004, 186-207; Knight 2003, 376-378). Käsitteitä, metodeja ja teorioita ei niin vain liikutella tieteenalalta toiseen ja harva väitöskirja tai muu tutkimus sopii sellaisenaan laajan yleisön luettavaksi. Vaikka tieteen yleiset pelisäännöt olisivatkin tuttuja, niin myös lähellä toisiaan olevien tieteenalojen keskinäinen vuoropuhelu saattaa tarvita popularisoinnin näkökulmaa. Esimerkiksi monitieteisissä konferensseissa, joissa pohditaan vaikkapa metsän merkityksiä, on asetelmaa hyvä miettiä ymmärrettäväksi tulemisen kannalta. Toisilleen etäisten alojen kohdalla yhteisen kielen löytäminen on vieläkin vaikeampaa. Omakohtainen varhainen kokemus oli "Metsä suomalaisten elämässä" -seminaarista vuonna 1986. Noihin aikoihin oli folkloristiikassa perinnelajianalyysin oheen tullut jo paljon muita lähestymistapoja. Monien eri alojen tutkijoiden ja ammattilaisten parissa metsäperinteen perinnelajilähtöinen tarkastelu osoittautui kuitenkin selkeäksi tavaksi kuvata "metsäkulttuurin" moninaisuutta. (ks. Virtanen 1987.)

Museon tekemä, tutkimusyhteisöä laajemmalle lukijakunnalle suunnattu julkaisu saattaa olla pätevää tiedettä, mutta näyttelyrintamalle siirryttäessä sisältöjen ja esityskeinojen tasapainottelu vaatii toisenlaista kirjoittamisen ja esittämisen otetta. 


\section{FOLKLORISTI MUSEOSSA}

Väitöskirjan voi kyllä ripustaa näyttelyksi sivu sivulta mutta näyttelymedia tarjoaa lähes rajattomasti mahdollisuuksia poiketa kirjallisesta esittämistavasta.

Näyttelytoimintaa ajatellen tiedeviestinnän ja popularisoinnin näkökulmat ovat mielenkiintoisia. Voiko näyttelyn rakentaa oikeaksi, vastaansanomattomaksi ja täydelliseksi? Pitääkö näyttelyn tavoitella ristiriidatonta, kaikille kelpaavaa tasapainoa? Mitä poimia esiin luonnon ja kulttuurin määrättömistä ilmiöistä? Miten olennaisen tiedon voi valikoida muutaman virkkeen mittaiseen tekstiosioon? Millaisia kuvia otetaan mukaan? Antaako postikortin kokoinen tehdaskuva todellisen kuvan laitoksen toiminnasta? Näyttelymedian keinot valoineen, tilaratkaisuineen, fontteineen, kuvineen, äänineen, hajuineen, kosketuspintoineen, esineineen ja liikkumissuuntineen tekevät tieteellisesti pitkällekin jäsennellystä kokonaisuudesta joka tapauksessa tulkinnan. Tutkimuksessa rajauksia joutuu tekemään esimerkiksi tieteenalan, aiheen ja lähestymistavan suhteen mutta näyttelyssä kuvapinta muodostuu lukemattomista muistakin osista. Näkökulmasta riippuen voi puhua näyttelymediasta tai siihen liittyen näyttelyestetiikasta.

Näyttelyn ja laajemmin popularisoinnin suuntaan liikuttaessa sisällöt koetaan usein alisteisiksi "oikealle" tutkimukselle. Näyttely on onnistunut, kun se kertoo elävöittävien kuvien ja esineiden kera tasapainoisesti tutkimustulokset. Silloin näyttelytoiminta on enemmän yksisuuntaista kansanvalistusta, tiedeviestintää, yleissivistyksen jakamista, opettamista ja faktatiedon jakamista. (vrt. Kiikeri ja Ylikoski, 188-195.)

Viestinnän näkökulmasta on jonkin verran tutkittu näyttelyjen kieltä ja sisältöjä. Myös folkloristiikan näkökulmasta näyttelyt kuten laajemmin koko museon toiminta voi tarjota hyviä tutkimuskohteita. Jos haluaa nostaa esiin nimenomaan folkloristisen kompetenssin, niin lipunkantajan rooliin on kuulunut esimerkiksi alaa lähellä olevien teemojen (kansanusko, "henkinen perinne"), perinnelajien (tarinat, sadut jne.) tai esitystapojen (esimerkiksi ääni) huomioiminen. Laajemmat perspektiivit löytyvät kuitenkin muualta. Esimerkiksi narratologiset ja sitä lähellä olevat lähestymistavat ovat mielenkiintoisia sekä näyttelyjen koostamisen kannalta että tutkittaessa näyttelyjen tai yleensä museotoimintojen sisältöjä (ks. esim. Aarnipuu 2008, Hatakka 2007).

Näyttelymedian moninaisten keinojen myötä on mahdollista siirtyä kertomusten ja tarinoiden tuolle puolen ja avata uusia, kriittisiä ja etäännyttäviä näkymiä, jota ei muunlaisin keinoin voi esittää. Sanojen, kuvien, tilojen, esineiden, teatterin, äänimaisemien ja muiden elementtien rinnastuksilla voi rakentaa maailmoja, jotka tietoisesti tavoittelevat käsitteiden täsmällisyydestä etääntyviä, muuntuvia ja omakielisiä kuvia. Kokonaista näyttelyä ajatellen Gaston Bachelardin sanoin voisi puhua rakennetusta "tilan poetiikasta" (ks. Bachelard 2003).

Bachelardin ja myös Maurice Merleau-Pontyn fenomenologiset lähestymistavat ovat vaikuttaneet suuresti uuteen arkkitehtuuriteoriaan ja näkymiä varmasti riittäisi yllin kyllin näyttelyihin suhteutettavaksi. Suomessa erityisesti arkkitehtuuria osittain edellisistä näkökulmien kautta ovat lähestyneet esimerkiksi Juhani Pallasmaa (2003) ja Kaj Nyman (2004). Mielen tilojen ja kerronnallisuuden yhdistäminen on mielenkiintoinen tapa pohtia näyttelyn ulottuvuuksia. Näistä käsin ei olla kovin kaukana folkloristin ajattelutavoista. 


\section{PekKa Virtanen}

Mutta ei saa olla liian tosikko kun esimerkiksi näyttelyistä on kysymys. NODEM-konferenssissa (teemana Experiences in Natural and Cultural Heritage) Reykjavikissa 3.-5.12.2008 Leidenin yliopiston Amalia Kallerg ja Marten Lamers painottivat projektinsa esittelyn yhteydessä sitä, että totuudenkertojan sijaan museolla on mahdollisuus ottaa kyselijän, kyseenalaistajan ja jopa provosoijan rooli. Taidenäyttelyissä yksittäisten töiden kautta piikkejä kyllä löytyy, mutta kulttuurihistoriallisissa näyttelyissä harvemmin.

\section{METSÄKUlTTUUURIA JA KULTTURIPERINTÖÄ}

Monet museot joutuvat resurssiensa vähäisyyden vuoksi keskittymään perustason tallennus- ja näyttelytoimintaan. Ääripään esimerkki on kesäsunnuntaisin talkoovoimin avoinna pidettävä kotiseutumuseo. Toisaalla isoilla museoilla saattaa olla mahdollisuus kehittää monipuolista yleisön, tutkijoiden ja asiantuntijoiden myötävaikutuksella tapahtuvaa toimintaa. Esimerkiksi Kiasmassa pohditaan paljon nykytaiteen sanomia ja ongelmia vuorovaikutteisesti sekä suuren yleisön että vierailevien ammattilaisten kanssa.

Metsään keskittyneen Luston tehtävänä on ollut tehdä näkyväksi ihmisen ja metsän vuorovaikutusta kautta aikojen menneisyydestä nykyisyyteen. Aluetta kutsutaan usein metsäkulttuuriksi, johon ongelmattomasti kytkeytyvät metsän sellaiset ulottuvuudet kuin kaski-, metsästys- tai jätkäkulttuuri. Metsäluonto- ja metsätalous-käsitteiden rinnalla metsäkulttuuri-termi voisi viitata olotilaan ja prosessiin, jossa ihminen ajatuksien ja tekemisten kautta havainnoi ja hyödyntää metsää ja sen tuotteita (kaukana metsästäkin). Tieteellisissä yhteyksissä metsäkulttuuri-käsite on kyllä ongelmallinen. Termi vaatii rajauksia ja täsmennyksiä, jos sitä ylipäätänsä haluaa käyttää. Samoin arkikäytössä sillä on ongelmansa. Metsäkulttuuri tuo helposti mieleen edesmenneet museoidut perinteet. Ja toisaalla kulttuuri viittaa korkeakulttuurin ja taiteen kenttään. Kummatkin ovat etäällä niistä tämän päivän kulttuurintutkimuksen tai arjen estetiikan sisällöistä, joita folkloristi, kulttuurintutkija tai museoammattilainen haluaisi painottaa. (Virtanen 1998, 26-33.)

Turun yliopiston folkloristiikan oppiaine-esittelyssä on onnistuneesti tiivistetty se, millaiseen asiantuntijuuteen toivoisi korkea-arvoisten huippukeskittymä-, tulevisuus-, brändi- ja kulttuurivientityöryhmien myös tukeutuvan:

"Folkloristiikka on yliopistollinen oppiaine ja tieteenala, joka antaa mahdollisuuden ymmärtää, tulkita, selittää ja hyödyntää oman maan ja maailman kulttuureita, suullista tai suullisperustaista sanataidetta, sanojen ja kertomusten perinnettä. Sen alaan kuuluu henkinen kulttuuriperintö, aineellisen kulttuuriperinnön symboliikka ja politiikka, kansallisen kulttuurin rakentuminen suullisen perinteen avulla, etnisyyteen ja etnisiin traditioihin liittyvät kysymykset, kulttuuriset identiteetit nyky-yhteiskunnassa, muistitiedon kautta jäsentyvä historiatieto, menneisyyskuvien roolit 


\section{FOLKLORISTI MUSEOSSA}

nykyisyyden rakentamisessa. Folkloristiikka on ajankohtainen tieteenala maailmassa, jossa kulttuurit sekä kohtaavat ja limittyvät että törmäävät toisiinsa." (Turun yliopisto, folkloristiikka, esittely).

Museoiden, muistiorganisaatioiden ja kulttuurintutkimuksen piirissä pohditaan paljon tämän päivän maailmanmenoa. Syystä tai toisesta kulttuuriperintö-asioista tietoa tarvitsevat eivät välttämättä tukeudu alan asiantuntijoihin. Kulttuuriperintö on ikään kuin museoitua ja arkistoitua ulkopuolista menneisyyttä, jonka voi tarpeen tullen kiinnittää juhlapuheisiin ja matkamuistoihin ja unohtaakin. Sinänsä on hienoa, että esimerkiksi Kansalliseen metsäohjelmaan 2015 on otettu mukaan "metsiin ja puuhun perustuva kulttuuri" ja "metsiin liittyvän kulttuurin kunnioittaminen, vaaliminen ja kehittäminen", mutta taustalla on vahva kulttuuriperinteen sällyttämisen lataus, eivät niinkään kulttuurin dynaamiset sisällöt (ks. Kansallinen metsäohjelma, 24-26).

Innovaatiokeskusten kulttuurin syvärakenteita koskevissa pohdinnoissa muistiorganisaatioiden ja kulttuurintutkijoiden aikajanat voisivat hyvin olla mukana rakentamassa tulevaisuutta sen sijaan, että sitä metsästetään markkinalähtöisten heikkojen signaalien kautta. Tulevasta huolta kantava yritys- ja yhteisötoiminta sekä kulttuuri(perintö)vastuu voisivat limittyä hyvinkin toisiinsa, jos ei vielä missio- niin ainakin visio-osastossa. Ympäristöön liittyvät kulttuurimerkitykset nousivat näkyvästi esiin ympäristötiedottajien ja ympäristötoimittajien yhteisessä kokoontumisessa Helsingissä 3.3.2009. Keskusteluissa tämän hetken tärkeäksi nähdyt ympäristöteemat jakautuivat neljään kenttään, joista yksi nimettiin kulttuurikentäksi. Ei niinkään yllättävästi siihen kuului paljon teemoja, joita on käsitelty 15 vuoden aikana avarassa ympäristöestetiikan konferenssisarjassa julkaisuineen. Viimeisin näistä, Taivaan ja avaruuden estetiikka -konferenssi, pidettiin Valamossa 26.-28.3.2009. 2000-luvulla ympäristö ja kulttuuri ovat nivoutuneet yhteen esimerkiksi kouluopetuksessa Suomen Tammen projekteissa (esim. Elo ym. 2002), isoissa tutkimus- ja tallennushankkeissa (esim. "Metsäammatit metsätalouden murroksessa" -hanke ja "Metsät ja hyvä elämä" -tutkimushanke) sekä uusissa ympäristön kulttuuriseen ja yhteiskunnalliseen tutkimukseen keskittyvissä verkostoissa (esim. Ympäristökulttuurin tutkijaverkosto). Vaikka kulttuuriperintöasioita vielä katsellaan yhtäällä menneisyyteen keskittyen, niin monet merkit kertovat myös toisenlaisista avarista näkymistä.

\section{LOPUKSI}

Folkloristi museotyöntekijänä ei ollut yleinen ilmiö 20 vuotta sitten, mutta sitä se ei ole vieläkään. Turun yliopiston folkloristiikan oppiaineen www-sivuilla museot kyllä mainitaan folkloristin mahdollisena työpaikkana esimerkiksi tiedottajana sekä museopedagogina (Turun yliopisto, folkloristiikka, työelämä). Moni turkulainen folkloristi onkin löytänyt työpaikan museosta. Helsingin tai Joensuun folkloristiikan uraopastuksissa mahdollista museoon sijoittumista ei vielä ole pidetty samalla tavoin maininnan arvoisena. 


\section{PekKa Virtanen}

Museoliiton 2003 tekemässä tutkimuksessa museossa työskentelevistä vain runsaalla prosentilla oli ollut pääaineenaan folkloristiikka (Museoväki'03) ja sama suhdeluku on myös uusimmassa kyselyssä (Museoväki' 08). Ulla Savolaisen kartoituksessa museologiaa Helsingissä luki 1996-2005 sivuaineena 106 vastanneesta folkloristiikan pääaineopiskelijasta vain kaksi (Savolainen 2007) eikä tilanne ole muuttunut suuresti sen jälkeenkään (Kotajärvi-Söderholm 2008).

1980-luvulla aineellisen ja henkisen kulttuurintutkimuksen selkeä erottaminen toisistaan sekä museologian oppimahdollisuuksien vähäisyys tekivät ymmärrettäväksi sen, että folkloristiikasta ei juuri suuntauduttu museoammatteihin. Tänä päivänä tilanne on kuitenkin toinen, sillä yhä useammat opiskelevat museologiaa ja perinneaineiden museaalisissa rajapinnoissa on väljentämisen varaa.

Valtion tukea saavien museoiden työntekijöiltä edellytetään entistä tiukemmin museologian opintoja ja/tai museoalan työkokemusta samalla kun halutaan korostaa museologisia, tieteellisiä työtapoja. Museologian merkitys on kasvanut samalla kun näyttelyihin, museopedagogiaan, tietotekniikkaan, asiakaspalveluun, tiedottamiseen, tapahtumien järjestämiseen ja moneen muuhun museotyöhön ymmärretään tarvittavan aiempaa laajempi kirjo eri alojen ihmisiä.

Turussa 15.-17.5.2008 järjestetyssä "Etnologian näkymät ja asema 2000-luvulla" -seminaarissa Outi Lehtipuro puhui jo 1960-luvulla vallinneista visioista hahmottaa laaja-alaisesti kansankulttuurin eri aineistot museoiden kokoelmat mukaan lukien (Lehtipuro 2008). Seppo Knuuttilan muistan monissa yhteyksissä puhuneen laajemminkin kulttuurintutkimuksen raja-aitojen höllentämisen tarpeesta. Omassa museotyössä folkloristiikan, etnologian, historian ja kulttuurintutkimuksen eri osaalueiden ja muistiorganisaatioiden sisällöt ovat risteytyneet jatkuvasti ja "henkisen perinteen", "suullisen perinteen" tai "kansanrunouden" ennakkomielikuvia on joutunut siinä kontekstissa korjailemaan useastikin.

Museossa on siis paljon liikkumavaraa myös folkloristille. Yllättävästi myös perinnelajibrändistä löytyy ajankohtainen täky. Eri tieteenalat ovat innolla ottaneet huomaansa "tarinan" (kerronnan, henkilökohtaisen kokemuksen, arjen jne.) ja sama koskee muiden tahojen ohella myös museoita. Tarinoiden kautta avautuvia näkymiä kaipaillaan kovasti, ja kukapas tuon ulottuvuuden tunteekaan paremmin kuin folkloristi?

Museot ovat 20 vuoden aikana avartuneet suuresti, mutta samalla tehtäväkentän laajuus on pitänyt niitä välillä liiankin hektisessä, luovuutta sekä tekemisen iloa karsivassa liikkeessä. Työmaita riittää tulevaisuudessakin. Helsingin kirjamessuilla 2008 pidetyssä museojulkaisuja käsittelevässä lähes sadan osallistujan seminaarissa keskustelua syntyi $\mathrm{mm}$. siitä, että näyttelyjen oheen museoiden oman väen voimin tehdyt julkaisut ovat melkeinpä poikkeuksetta tehty varsinaisen työajan ulkopuolella. Ulkopuolista työvoimaa voidaan kuitenkin ottaa näyttelyihin tai erilaisiin projekteihin, eikä uusiin avauksiin suhtauduta suinkaan karsaasti, varsinkin jos on tiedossa ulkopuolista rahoitusta ja uudenlaisia toimintamalleja.

Matti Räsänen tarkasteli lähes neljännesvuosisata sitten kansatieteen merkitystä museoissa ja tähdensi erityisesti museoiden ja yliopiston yhteistyön merkitystä (Räsänen 1985). Kansatieteilijän asema museossa oli esillä myös Ethnoksen etnologian 


\section{FOLKLORISTI MUSEOSSA}

ja kansatieteen asemaa tulevaisuuden yhteiskunnassa tarkastelleessa Vaihtuvat visiot -seminaarissa Helsingissä 13.3.2009. Laajoihin uhkakuviin ja visioihin ei aiheesta esitelmöinyt Solveig Sjöberg-Pietarinen mennyt. Enemmän toiveena oli lisätä perinteisten taitojen tuntemista ja jopa käytännön osaamista. Esitelmää seuranneissa kommenteissa nousi enemmän esiin isot asiat. Anne Ala-Pöllänen korosti tarvetta rytmittää oikealla tavalla museologian rinnalle muut (pääaine)opinnot ja sisäistää hyvin museotyöhön kuuluvat ihmisläheisen arjen käytännöt ja merkitykset, ei vain historiallisia reunaehtoja. Historiatieteen näkökulmat eivät myöskään ole ainoita seurattavia johtolankoja ajateltaessa viime aikojen toiveita saada uusi Suomen valtiollisen historian museo tai näyttely. Kun sellainen lähtee toteutumaan, arjen ja tarinoiden pohtimiseen löytyy runsaasti tässäkin katsauksessa kuulutettua folkloristista asiantuntemusta.

\section{LÄHTEET JA KIRJALLISUUS}

AARNIPUU, PETJA 2008: Turun linna kerrottuna ja kertovana tilana. Helsinki: SKS.

BACHELARD, GASTON 2003: Tilan poetiikka (1957). Helsinki: Kustannusosakeyhtiö Nemo. 3. painos.

Connecting and collecting - 30 years of Samdok. Samtid \& museer No 2, 2007.

DROIT, ROGER-POL 2005: Esineiden luonto. Jyväskylä: Tammi.

ELO, PEKKA ja JÄRNEFELT, HELJÄ ja PAALANEN, TOMMI (toim.) 2002: Elävää kulttuuriperintöä. Opetushallitus.

HALONEN, TERO 2008: Maasta ja puusta pidemmälle. Helsingin yliopiston maatalousmetsätieteellisen tiedekunnan historia, I osa. Helsinki: Helsingin yliopiston maatalousmetsätieteellinen tiedekunta.

HATAKKA, MARI 2007: Narratiivisen käänteen vaikutus museoiden toimintaan ja tutkimukseen. Elore 1/2007. www.elore.fi/arkisto/1_07/hat1_07.pdf [16.3.2009]

Museoväki'03. http://www.museoliitto.fi/doc/museovaki03.pdf [16.3.2009]

Museoväki'08. http://www.museoliitto.fi/museovaki08 [16.3.2009]

KIIKERI, MIKA ja YLIKOSKI PETTERI 2004: Tiede tutkimuskobteena. Helsinki: Gaudeamus. 2. painos.

KNIGHT, JONATHAN 2003: Clear as Mud. Nature vol 423, 22 May 2003, 376-378.

KOTAJÄRVI-SÖDERHOLM, SANNA 2008: Helsingin yliopistossa vuosina 2004-2006 folkloristiikan opiskelijoina aloittaneiden alanvalinta ja työllistymisodotukset. Pro-gradututkielma. Helsinki: Helsingin yliopisto, kulttuurien tutkimuksen laitos.

LEHTIPURO, OUTI 1995: Museon kaksi kulttuuria. Museo 4/1995.

- 2008: 2000-luvun unelma kokonaisvaltaisesta etnologiasta. Abstrakti. Etnologian näkymätja asema 2000-luvulla. Seminaarijulkaisu. Turku: Turun yliopisto, kulttuurien tutkimuksen laitos.

NYMAN, KAJ 2004: Arkkitehtuuri ruumiillisuutena ja representaationa. Teoksessa Mäntysalo, Raine (toim.) 2004: Paikan heijastuksia. Jyväskylä: Atena Kustannus.

PALLASMAA, JUHANI 2003: Tilan poetiikka ja arkkitehtuurin teoria. Teoksessa Bachelard, Gaston 2003: Tilan poetiikkea. Helsinki: Kustannusosakeyhtiö Nemo. 3. painos. 


\section{Pekka Virtanen}

PENNANEN, JUKKA 1985: Tiedekeskus pölistelee museota. Museo 6/1985.

Turun yliopisto, folkloristiikka, esittely. http://www.hum.utu.fi/oppiaineet/folk/ esittely/ [16.3.2009]

Turun yliopisto, folkloristiikka, työelämä. http:/ /www.hum.utu.fi/oppiaineet/folk/ esittely/työelämä/ [16.3.2009]

RÄSÄNEN, MATTTI 1985: Museot ja yliopisto kansatieteilijän silmin. Museo 6/1985.

SALMI, HANNU 2001: Public understanding of science: universities and science centers. Management of University Museums. Education and skills. OECD, Paris.

SARESSALO, LASSI 1982: Folkloristiikkako museoaineeksi. Museopolitiikka 1/1982, 3-5.

- 1994: Voidaanko identiteettiä museoida. Museo 3/1994.

SAVOLAINEN, ULLA 2007: Kulttuurien tutkimuksen laitokselta valmistuneiden maistereiden työllistyminen. Arkeologien, folkloristien ja kansatieteilijöiden sijoittuminen työelämä̈̈n vuosina 1996-2005. Helsinki: Helsingin yliopisto, kulttuurien tutkimuksen laitos.

STARK, MARIA 2008: Koru - enemmän kuin materiaa. Koruun liitetyt kollektiiviset käsitykeset Koru kertoo kantajastaan -kirjoituskilpailun valossa. Pro-gradu-tutkielma. Helsinki: Helsingin yliopisto, kulttuurien tutkimuksen laitos.

VILKUNA, JANNE 2003: Täytetyn tiikerin äärellä - museologia, mitä se on? Tieteessä tapabtun $7 / 2003$.

VIRTANEN, PEKKA 1987: "Kansanperinteen metsäkuvia." Silva Fennica 4/1987.

- 1997: På en museiresa till skogen. Nord Nytt 68/1997.

- 1998: Tuohikulttuurista metsäkulttuuriin. Vuosilusto 96-97.

- 2007: Näyttelyitä koko kansalle. Museo 1/2007.

- 2008: Oppeja museotyöhön. Museo 3/2008.

FM Pekka Virtanen työskentelee ympäristökulttuuriin liittyvissä tutkimus-, museo- ja näyttelyprojekteissa ja on folkloristiikan jatko-opiskelijana Helsingin yliopistossa. 